Throughout the pageantry, the wealth and splendour of display of personal adornment, dress, and equipment vividly described in, for example, the dispatches of the correspondent of The Times in the issues of February 23 and 24, there is apparent an all-embracing current of mystic symbolism which endues every act, every movement and every attendant circumstance with the significance of worship, and of recognition of the spiritual influence which centres in and emanates from the person of the reincarnated head of the Tibetan spiritual and political hierarchy. It is this, and not the fact that such ceremonial has not been enacted in Lhasa for the space of sixty years, which animated the crowds through which the Dalai Lama was carried in his golden palanquin to the Potala, and on the following day added a solemn meaning to the blessings of a child conferred on the elders of church and State and later sanctified what was otherwise an unseemly scramble for the Dalai Lama's food as a re-enactment of the ancient ritual of sharing in the flesh of the sacrificial victim.

\section{Relics of the Buddha}

BudDhisw of another order, but nevertheless of a closely related world of thought, appears in the announcement that Buddha relics of exceptional sanctity, discovered in Central India nearly ninety years ago and since in private possession in England, will now return to the East. They have been given to a Buddhist Temple in Ceylon by Mrs. Leslie Smith and Mrs. Winifred Burrows, granddaughters of General F. C. Maisey, by whom they were discovered when with Sir Alexander Cunningham he was investigating the numerous Buddhist monuments around Bhilsa in 1851. The discovery, as described in The Times of February 27, consisted of a relic casket-a small crystal tope, with terrace, plinth, hemispherical dome, square pedestal and a double pinnacle, this last forming the stopper of a small perpendicular shaft. This casket has been dated at about 350 B.c. The relic ehamber at the bottom of the shaft contained minute pieces of bone, the whole being enclosed in a red earthenware box, which also contained other pieces of bone, and a series of the seven precious things usually accompanying the relics of an eminent person, namely, thin round pieces of gold, a bead of garnet, a crystal bead, two beads of pale greenish crystal, and some minute fragments of pearl.

The casket is now in the India Section of the Victoria and Albert Museum, South Kensington; but a cast and photographs have been supplied by the authorities in order that a replica may be made in Ceylon by native craftsmen. The relics and the seven precious things, which were retained by General Maisey when he presented most of the antiquities to the Museum, have now been enclosed in a carved silver tope from Ceylon for their conveyance to the island.

\section{Sutton Hoo Burial a Cenotaph?}

IN an account of the excavation of the Sutton Hoo ship-burial and of the associated antiquities delivered before the Society of Antiquaries of London on
February 22 (see Nature, Feb. 10, p. 231), Mr. C. W Phillips referred to the remarkable feature of the deposit that it did not accompany a body. The explanation which he put forward on certain grounds was that the mound and its contents as a whole had the character of a cenotaph for a great man whose body could not be recovered, possibly through being lost at sea. One suggestion which has been offered, namely that it may have been a measure of insurance on the part of a recently Christianized pagan in an endeavour to make the best of both alternatives, is perhaps not to be taken seriously. Nevertheless survival of a pagan ritual, even in such an essential rite as burial, cannot be ruled out entirely; and it receives a certain amount of support from the archaic character of the ship, of which some further account was given.

The excavation of the ship was under the direction of Lieutenant-Commander J. K. D. Hutchinson of the Science Museum, South Kensington. It proved to be a remarkable vessel in the form of an open barge, clinker-built, keel-less, and propelled by at least thirtyeight oars. It was described as a development of a type already known to archaeologists, and, it may be supposed, of a type already archaic at the time of its burial. In its character as a royal barge, a comparison was instituted with the position of the royal yacht Victoria and Albert among contemporary shipping. This view would accord with the interpretation of the find which emphasizes its highly ceremonial nature. At the same time it may be recalled that ship models found by the Danish Thule Expedition to Greenland pointed to Norse ships still being in use of which the essential features had remained unchanged for a period of nearly six hundred years.

\section{Cosmic Rays}

THE twenty-fourth Guthrie Lecture of the Physical Society was delivered by Prof. P. M. S. Blackett on February 26. He took as his subject "Cosmic Rays : Recent Developments". He said that the most important discovery of recent years in the field of cosmic rays was the realization that the hard or penetrating component of the rays consists of particles of a new type, called mesotrons. This new particle has a mass intermediate between that of the electron and the proton and possesses the peculiar property of being spontaneously unstable. Its average life when at rest is about one millionth of a second, but when moving fast it lives longer-thus giving a nice verification of Einstein's principle of relativity.

The rays incident on the earth's atmosphere are of very great energy. Recent work shows that some of the rays have an energy certainly as high as one thousand million million volts. This is an astonishingly great energy, and it is probably not the limit. It is quite likely that rays exist with energy as high as a million million million volts or even more. Particles of such great energy have very peculiar properties. Instead of producing a narrow track of ionization a fraction of a millimetre broad like normal atomic tracks, they make a track many metres broad. This is deduced from relativity theory, but has not 